THE DEPOPULATION OF CIVILIZED NATIONS.

Read by title in the Section on State Medicine, at the Forty-sixth Annual Meeting of the American Medical Association,

at Baltimore, Md., May 7-10, 1895.

BY H. B. McKLVEEN, M.D.

CHARITON, IOWA.

You see the title I have given to this paper is the depopulation of civilized nations. Probably it would be more proper to put it, the cessation of increase of population; for it is not so much the causes that depopulate, that I wish to speak of, as the causes which hinder the increase of the population,

It seems that the people of all civilized nations have in matters relating to the perpetuation of the species become subject to some influence, which as the nation becomes cultured prevents its increase. They seem to be approaching the same finale that characterizes a certain variety of butterfly which attains the perfect state and then dies.

In this country the subject does not receive the attention it merits, in fact it only attracts the notice of medical men, and then not as a condition which may confront them, but rather as a curiosity.

In France a great deal of attention has been paid to this matter. In 1891 one-fourth of the papers submitted to the Academy of Sciences were upon this subject The result has been that active efforts have been $m$ ade by legislation to increase the number of births and to protect the lives of those that may be born.

In most European countries reliable statistics exist by which we can determine the ratio between births and deaths, but in the United States we have no very exact figures with which to compare ourselves with other countries.

France in 1890 had over 100,000 more deaths than births.

England, though not so bad, showed a greater mortality than natality.

Germany makes a better showing than any nation of Europe, except Austria. In Germany the births slightly exceed the deaths.

In Austria the natality is 65 per 1,000 of the population and the mortality 49 per 1,000 .

In 1880 in the United States there were born 37 per 1,000 of the population, while in 1890 the rate had fallen to $29 \frac{1}{2}$ per 1,000 .

This condition existing as it does in times of peace, when there is neither famine nor plague to increase the mortality and with every effort made by science to lengthen life, becomes really alarming.

With compulsory vaccination to prevent smallpox, better hygienic conditions in our cities, a greater knowledge of sanitary laws and the advancement of medicine and surgery, the mortality has decreased in all countries. In France, alone, the deaths have in twenty-five years decreased over 100,000 annually.

What is the cause of this falling off in the number of births? We should expect an increase, since science has done so much to rob child-bearing of its horrors.

Demographers differ as to the cause. Among those mentioned are the late age at which the young people are now married. This decreases the fertile period; the obstacles in the way of legal formalities; the financial embarrassment of large families; the exactions of military service; the unequal emigration of adult celibates; the tendency of people to go to the cities to reside; unhygienic modes of living; the common practice of abortion.
In our own country not all of these mentioned causes can be held accountable; for instance, there are very few Iegal formalities connected with marriage.

Compulsory military service is unknown in our country, but in continental Europe every young man has to serve a certain part of his best days, and it is a decided hindrance to his marrying as soon as he otherwise might.

At the present time, marriages are consummated at a much later age than formerly. This is due to several reasons: the lengthened educational course is one; the young men and women of to-day are just finishing their education at an age at which their parents became father and mother.

of course education is a good thing for the individual, but our present systems of education seem to be playing sad havoc with the birth rate and this will be more noticeable in the future, because of the fact that education is becoming more general. Another cause might be mentioned: the young men feel the necessity of having something ahead in a pecuniary way, in order that they might begin their married career in a manner commensurate to their former method of living.

We are living in an age of luxury, and things that were considered luxuries in the past are necessities at present.

Bunyan, the author of the immortal "Pilgrim's Progress," said that when he and his wife were married they had neither pot nor spoon betwixt them. How many couples at the present day would marry under such conditions, which up to fifty years ago were common enough?

At the present time, with few avenues to wealth open before him, the young man is very much older by the time he has sufficient laid by on which to marry than were his ancestors.

One of the most potent causes of the decrease in births is the tendency of people to flock to the cities. Children which are an actual source of wealth to the man in the rural districts, become a source of expense to the urban resident. This causes them from necessity to limit their families. I might mention the desire of parents to give their children exceptional educational advantages. This causes them, when only of moderate means, to wish that they have but few children, especially if they are to distribute their favors equitably.

The wealthy are best able to properly raise large families but, as a rule, they are the ones who have the fewest children. The social pleasures which the rich women can enjoy cause them to abhor maternity, because it interferes with their imagined happiness. Among the poor in the cities, children are particularly a great burden, for it is often necessary in order to live, that the wife shall leave home to labor, and this she can not do and raise a family.

1. I might here state that only one-fifth of the women are able to nurse their offspring as nature intended. No wonder that 26 per cent. of the children die in their first year, for no food man can compound is equal to that nature provides. Why this inability to nurse children? In the first place, the waists and breasts of our women are compressed by tight lacing, tight clothing, corsets, stays and all that is necessary to make a fashionable figure. This causes chronic induration of the breasts, and has a tendency to prevent secretion and in many cases abscesses form. 
2. The lungs are so compressed as to prevent proper oxygenizing of the blood.

3. The abdominal and pelvic organs are so displaced that digestion is impaired and the pelvic viscera are in a state of passive congestion with all the attendant evils, rendering the woman unable to furnish the proper nourishment for her child.

Women have until very recent years been taught that they should do nothing which compelled them to come in contact with the public. Now all is changed, and we find women engaged in nearly every vocation. What is the result? They take the place formerly occupied by men, at a much reduced salary. The consequence is that thousands of men who did " earn good salaries are now filling the ranks of the army of the unemployed. Five thousand clerks, bookkeepers and stenographers were fed daily at the soup kitchens in Chicago during the winter of 189394, whose places are now filled by women. Had these men kept their positions they would have married, perhaps had a family of two or three children. The women who engage in these vocations do so at the expense of their domestic education.

I will now mention another cause of reduced natality - a cause that, did it not exist, we should have much less reason to look with alarm upon decreasing natality. I have reference to the common crime of abortion. So prevalent is this practice that I doubt if an audience of laymen of any size can come before a speaker, but that he faces some one who is guilty of this crime.

Charpentier relates an incident of a doctor in France who was indicted for this crime and confessed to having produced over five thousand abortions. Suppose that one-half of these had attained adult life. There would be enough to make a city of 2,500 inhabitants. Again, suppose that some catastrophe should happen that would kill every one of these people. What an appalling disaster this would be! The whole world would hear of it. Pages in the newspapers would be devoted to it. Every one would mourn the loss. But when one man slaughters 5,000 of the innocents, we only know of it as an incident of medical importance.

In France the practice is much more common in proportion to the population than in our own country, due perhaps to the lower moral status of the people. It is estimated that in France alone half a million abortions are annually produced. I have never seen statistics relative to the number in our own country.

Upon what the demographer based his calculations I can not say. The figures may or may not be too great, but we do know that were there no criminal abortions produced, there would be little probability of the race becoming extinct.

I have asked a number of physicians how often they are approached by persons desirous of having them produce abortions. The average was twice a month. Were this true the country over, this would mean that the physicians of the United States were asked 3,120,000 times a year to produce abortions. The same individual may ask twenty different doctors before finding one who will do the work. Millions and millions the world over are annually produced and we hear but very little of it.

I have now spoken of the principal causes of the decrease in the number of births. I might say I have diagnosed the case. Now, what treatment should be employed? For one thing, this crime should be denounced by the clergy. How often have those of you who attend church heard scathing denunciations from the pulpit upon such minor crimes as the use of liquor, tobacco, etc., ad infinitum. Did any of you ever hear the crime of abortion mentioned, and yet I doubt if any minister can look down on his congregation when two thirds of the pews are filled, but that there is some one within hearing of his voice who is guilty of this crime. A clergyman asked a doctor I know why he did not attend church. He replied he was in better company when with the loafers on the street. "How so, doctor?" said the clergyman. "Well," answered the doctor, "when in church I see so many who are guilty of having committed abortion, which is a form of murder, who seem to take such an active part in church work that it seems like a travesty on religion, and so I stay away. When I am with the loafers I am with immoral men, but not murderers."

The doctor may have been too hard on them or else he possessed an intimate knowledge of the community, but such is often the case; those whom you least suspect are most guilty.

It should be a part of the religious and moral training of every young man and woman to be made aware of the heinousness of this crime. Every mother who calls herself a Christian should teach her sons and daughters that it is murder and nothing else. Murder in its worst form, for it is unprovoked and premeditated. Better a thousand times had she who thinks of doing this crime let nature take its course and let her bury herself in obscurity, be she single, until she can again mingle with the world. France has many public maternities where these unfortunate women can go, and they use them too, for one of every eight children born in that country are illegitimate.

A true physician should consider it an insult to be approached by any one desirous of having him produce an abortion. Some doctors in refusing seem to apologize for so doing. It is within the power of the physician to do much toward stopping this practice of abortion, by showing up the criminal phase and the physical dangers.

The newspapers, the great educators of the people, should refuse to advertise for these abortionists who by carefully worded personal notices inform the unfortunate where they can get relief. In one issue of the Chicago papers, I found over a score such notices Although it is against all law, yet no convictions take place worth mentioning and when they do it. nearly always savors of blackmail.

The educational methods should be changed, so that the student may receive physical training and hygienic knowledge. You can not have a sound mind in an unsound body. A lack of domestic education leaves the woman unfitted to make a home what a home should be, and much discomfort and unhappiness may result from such ignorance. Girls should be taught that woman's sphere is, first of all, a domestic one; her first duty is to her family and her home. What man would desire a woman who knew nothing of domestic duties?

The tendency of people to flock to the cities is one of the things that work to decrease population and one of the hardest to remedy. Farm life is gradually becoming more attractive and we may hope that the future may change this migration. Thousands in 
the cities are merely existing, who have strength and ability to prosper in the country if they would be willing to sacrifice their love for the city's hustle and bustle.

In France every method has been tried to increase the birth rate. A premium paid for each child born; taxes regulated so that the man with a large family would have less to pay; maternities established, but all in vain. Despairing of attaining an increase in birth, they now seek to preserve the lives of those that are born. Laws to preserve the little ones have been passed. It is a misdemeanor punishable by very heavy fines to give a child less than a year old any sulid food, save by physician's orders. I doubt if legislation will ever do much to remedy these conditions. We can at best only hope that an evolution may take place, but for the present and immediate future, I think that the theories of Darwin and Herbert Spencer will hold good.

The increase of natality is in inverse proportion to the efforts of the individual to climb the social scale, and the development of a nation in numbars is in inverse proportion to the refinement and social ambition of the individual.

\section{ENTERIC FEVER IN INFANCY.}

Read in the Section on Diseases of Children at the Forty-sixtb Annual Meeting of the American Medical Association at Baltimore, Md., May 7-10, 1895.

BY WM. B. NOYES, M.D. NEW YORK.

The subject of typhoid fever in infancy is one which has been much discussed, recently and in former years, but it is brought up again for new study because of the great uncertainty which still exists in the minds of many in regard to its occurrence, the indefiniteness of most of the literature on the subject, and the very great importance which the exact knowledge of typhoid fever must always have in all its different phases.

In medical literature, recent and old, some authorities of high repute speak of having seen scores of cases in early infancy and childhood and consider the disease not uncommon. The other extreme is represented by Northrup, of New York, who is exceedingly skeptical of its occurrence in infancy. His belief is based on his experience in the last twelve years at the New York Foundling Asylum where 1,800 children constantly under observation living inside and outside of the hospital, liable to every possible exposure which New York city can furnish, have never at any time developed a single case in children under 3 years of age.

Dr. O'Dwyer, with twenty years' experience in the same institution, has seen nothing of it. The physicians of the New York Infant Asylum, a smaller but active children's service, have never observed it. The Nursery and Child's Hospital does not record it. The Children's Hospital of Philadelphia, the largest service in the United States, according to the statement of the resident physician, Dr. Page, has never had a case of typhoid fever in early infancy.

With these statements and the negative records of most institutions in this country in regard to the occurrence of typhoid fever at this age, you will realize that it is necessary to study very carefully the following statistics which I have collected from the entire medical literature on the subject, after which a careful discussion may enable us to reach more positive conclusions than have hitherto been possible:
I.-TYPHOID FEVER IN ENGLISH EPIDEMICS.

1. In London epidemics, according to the British Medical Journal, 1882, there occurred in 1870-71, 126 deaths under 5 years of age, or 18 per cent. of all cases. In 1880 there occurred fifty eight deaths under 5 years, or 13 per cent. of all cases. In 1881 , eighty-three deaths under 5 years, or 8 per cent of all cases.

2. In an epidemic in Stockport, England, 1890, there occurred 218 cases, 8 of which were under 5 years of age.

3. In Southend, Essex, from January to October, 1890 , out of 152 cases, 65 per cent. occurred under 15 years, 13 per cent. under 5 years, including a male infant under 1 , nine boys under 5 .

4. Murchison reports in 5,911 cases of typhoid fever in the London Fever Hospital fifty-eight cases, thirtyfour females, twenty-four males, under 5 years of age.

5. St. Thomas Hospital Reports record from 1878 to 1880,3 cases under 5 years, out of 124 cases of typhoid fever.

6. St. Bartholomew Hospital Records from 187580 report out of 113 cases of typhoid fever 9 under 5 , with 1 death.

7. Homerton Fever Hospital Records show an average of 2.4 per cent. of their cases of typhoid fever from birth to 4 years, 11.24 per cent from 5 to 9 years.

8. The Metropolitan Asylums Board, of London, representing nine fever hospitals record from 1871-93, 266 cases of typhoid fever under 5 years, with 33 deaths.

Of cases older they report: From 5 to 10 years, 1,143 cases, mortality 102 , or 8.9 per cent.; 10 to 15 years, 2,019 cases, mortality 265 , or 13.1 per cent.; 15 to 20 years, 1,955 cases, mortality 346 , or 17 per cent.; over 40 years, 338 cases, mortality 96 , or 29.3 per cent.

The Northwestern Hospital alone, from 1889 to 1893 , had 101 cases of typhoid under 5 , with 9 deaths. II.-EPIDEMICS OF TYPHOID FEVER ON THE CONTINENT.

1. Gassicourt, out of eighty-five cases of typhoid in Hospital Trousseau, Paris, records three cases from 1 to 2 years, eight from 2 to 5 years, thirty-four from 5 to 10 , of which fifty-five were mild, twenty-two moderate, eight severe, and four fatal, or 4.6 per cent. (Rev. des Maladies de L'Enfance, 1890.)

2. In Berlin, 1878, 623 deaths from typhoid were reported, of which 98 were under 5,39 from 5 to 10 , (Keating, Arch. Pediatrics.)

3. In Heidelberg, from 1861 to 1879 , Roth in the Arch. fur Kinderheilkunde, 1881, reporte eighty-two cases in the Luisenarstalt and Polyclinic under 15, five under 5 (one in the first year, three in the second) thirty cases from 5 to 10 . These are epidemic cases. 4. In Gerhardt's Kinderkrankheiten, vol. I, page 50 , Wolff states that in an epidemic at Erfurt, 23.6 per cent. of all fatal cases occurred in children. From birth to 1 year, 7.5 per cent; 1 to 2 years, 12.7 per cent; 3 to 5,42 per cent; 6 to $10,28.2$ per cent.

5. In Basel, out of 2,213 fatal cases of typhoid fever, between 1824 and 1873 , from birth to 5 years occurred 108 cases; from 6 to 10 years, 85 cases. (Same authority.)

6. Barthez and Rilliet (Maladies des Enfants) studied 1,113 cases of typhoid which passed under their observation; of these 90 cases occurred from 2 to 4 years, mortality 25 per cent.; 176 occurred from 5 